\title{
Curtobacterium ginsengisoli sp. nov., isolated from soil of a ginseng field
}

\author{
Myung Kyum Kim, Yu-Jin Kim, Ho-Bin Kim, Se-Young Kim, Tae-Hoo Yi \\ and Deok-Chun Yang
}

Correspondence

Deok-Chun Yang

dcyang@khu.ac.kr
Korean Ginseng Center and Ginseng Genetic Resource Bank, Kyung Hee University, \#1 Seocheon-dong, Giheung-gu Yongin-si, Gyeonggi-do 449-701, South Korea
A Gram-positive, non-motile, pale-yellow, short rod-shaped bacterium, strain DCY $26^{\top}$, was isolated from soil of a ginseng field in South Korea and was investigated to determine its taxonomic position. The organism grew optimally at $30-37{ }^{\circ} \mathrm{C}$. The $\mathrm{G}+\mathrm{C}$ content of its DNA was $65.8 \mathrm{~mol} \%$. Phylogenetic analysis based on 16S rRNA gene sequences revealed that strain DCY $26^{\top}$ was related most closely to species of the genus Curtobacterium, in the family Microbacteriaceae. Strain DCY $26^{\top}$ showed highest $16 \mathrm{~S}$ rRNA gene sequence similarity to Curtobacterium pusillum DSM $20527^{\top}$ (96.3\%), Curtobacterium luteum DSM $20542^{\top}(96.2 \%)$, Curtobacterium flaccumfaciens LMG $3645^{\top}$ (96.2\%), Curtobacterium citreum DSM $20528^{\top}$ (96.1\%), Curtobacterium albidum DSM $20512^{\top}$ (96.1\%) and Curtobacterium herbarum DSM $14013^{\top}(95.3 \%)$. The predominant menaquinone of strain DCY $26^{\top}$ was MK-9. Other chemotaxonomic data also supported the affiliation of strain DCY $26^{\top}$ to the genus Curtobacterium. On the basis of its phenotypic properties and phylogenetic distinctiveness, strain DCY $26^{\top}$ is considered to represent a novel species of the genus Curtobacterium, for which the name Curtobacterium ginsengisoli sp. nov. is proposed. The type strain is DCY $26^{\top}(=\mathrm{KCTC}$ $13163^{\top}=$ JCM $14773^{\top}$ ).
The family Microbacteriaceae, proposed by Park et al. (1993), comprises more than 20 genera, including the genus Curtobacterium. The genus Curtobacterium was established by Yamada \& Komagata (1972) to accommodate six species, namely Curtobacterium albidum, C. citreum, C. luteum, C. pusillum, C. saperdae and C. testaceum. Four other species were later added to the genus: Curtobacterium flaccumfaciens (Hedges 1922) Collins and Jones 1984, C. plantarum Dunleavy 1989, C. herbarum Behrendt et al. 2002 and C. ammoniigenes Aizawa et al. 2007. C. saperdae and $C$. testaceum were subsequently transferred to the genus Microbacterium (Takeuchi \& Hatano, 1998), and C. plantarum was transferred to the genus Pantoea (Gavini et al., 1989). At the time of writing, the genus Curtobacterium thus comprises seven recognized species.

In a series of studies, we attempted to isolate microorganisms from soil in order to investigate the community structure based on a culture-dependent method. In the present study, a Curtobacterium-like bacterium, designated strain DCY26 ${ }^{\mathrm{T}}$, was isolated from soil of a ginseng field in Daejeon city, South Korea, and was characterized based on a polyphasic approach. Phylogenetic analysis based on $16 \mathrm{~S}$ rRNA gene sequences, determination of genomic relatedness and tests of chemotaxonomic and phenotypic

The GenBank/EMBL/DDBJ accession number for the 16S rRNA gene sequence of strain $\mathrm{DCY}^{2} 6^{\top}$ is EF587758. properties were conducted to determine the precise taxonomic position of strain DCY $26^{\mathrm{T}}$. The results indicate that strain DCY $26^{\mathrm{T}}$ represents a novel species of the genus Curtobacterium.

Strain DCY $26^{\mathrm{T}}$ was isolated from surface soil of an agricultural field where ginseng was planted. One gram of the soil was immersed in $50 \mathrm{ml}$ saline solution, vortexed and serially diluted and a $100 \mu \mathrm{l}$ aliquot was inoculated on ten-fold-diluted R2A agar (Difco). Single colonies on these agar plates were purified by transferring them onto new plates and subjecting them to an additional incubation for 5 days at $30{ }^{\circ} \mathrm{C}$. The purified colonies were tentatively identified based on analysis of the partial 16S rRNA gene sequence.

Cell morphology and motility were observed with a Nikon light microscope $(\times 1000$ magnification), with the cells being allowed to grow for 5 days at $30{ }^{\circ} \mathrm{C}$ on $\mathrm{R} 2 \mathrm{~A}$ agar. Gram reactions were conducted according to the nonstaining method as described by Buck (1982). Oxidase activity was evaluated via the oxidation of $1 \% p$ aminodimethylaniline oxalate. Catalase activity was determined based on measurement of bubble production following the application of $3 \%(\mathrm{v} / \mathrm{v})$ hydrogen peroxide solution. Growth at various temperatures $(4,15,25,30,37$ and $42{ }^{\circ} \mathrm{C}$ ) was assessed on R2A agar and growth at different $\mathrm{pH}$ values was assessed in R2A broth. Growth on 
nutrient agar, Luria-Bertani agar and trypticase soy agar was also evaluated at $30{ }^{\circ} \mathrm{C}$. The API 20NE, API ID32 GN and API 32 ZYM microtest systems were employed according to the recommendations of the manufacturer (bioMérieux).

Isoprenoid quinones were extracted with chloroform/ methanol $(2: 1, \mathrm{v} / \mathrm{v})$, purified via TLC and subsequently analysed by HPLC as described by Collins \& Jones (1981) and Shin et al. (1996).

For determination of the $\mathrm{G}+\mathrm{C}$ content, genomic DNA was extracted and purified with the a 100/G genomic-tip system (Qiagen) and was then enzymically degraded into nucleosides. The nucleosides were analysed by using HPLC as described by Tamaoka \& Komagata (1984) and Mesbah et al. (1989).

Genomic DNA was extracted and purified with the Genomic DNA isolation kit (Core Bio System). The 16S rRNA gene was amplified from chromosomal DNA by using the universal bacterial primer set $9 \mathrm{~F}$ and $1512 \mathrm{R}$ (Weisburg et al., 1991), and the purified PCR products were sequenced by Genotec (Daejeon, Korea) (Kim et al., 2005). The full sequence of the 16S rRNA gene was compiled with the SeqMan software and 16S rRNA gene sequences of related taxa were obtained from GenBank and edited by using the BioEdit program (Hall, 1999). Multiple alignments were performed with the CLUSTAL_X program (Thompson et al., 1997). Evolutionary distances were calculated by using Kimura's two-parameter model (Kimura, 1983). A phylogenetic tree was constructed via the neighbour-joining method (Saitou \& Nei, 1987) in the MEGA 2 program (Kumar et al., 2001). Bootstrap analysis based on 1000 replicates was also conducted in order to obtain confidence levels for the branches (Felsenstein, 1985). All recognized species of the genus Curtobacterium and related genera were included in the phylogenetic tree.

Strain DCY $26^{\mathrm{T}}$ was cultured on R2A agar at $30{ }^{\circ} \mathrm{C}$, yielding pale-yellow, circular colonies. Cells were Gram-positive, non-motile, short rods. Strain DCY $26^{\mathrm{T}}$ was able to grow at $25-42{ }^{\circ} \mathrm{C}$ but not at $4{ }^{\circ} \mathrm{C}$. Results relating to the physiological characteristics of strain $\mathrm{DCY} 26^{\mathrm{T}}$ are summarized in the species description, and a comparison of selective characteristics with the type strains of related species is provided in Table 1.

The major cellular fatty acids of strain $\mathrm{DCY} 26^{\mathrm{T}}$ were anteiso- $\mathrm{C}_{15: 0} \quad(54 \%)$, anteiso- $\mathrm{C}_{17: 0} \quad(29 \%)$, iso- $\mathrm{C}_{16: 0}$ $(11 \%)$ and iso- $\mathrm{C}_{15: 0}(4 \%)$. This profile of major fatty acids is common to members of the genera Curtobacterium and Rathayibacter. Strain DCY $26^{\mathrm{T}}$ contained menaquinones with nine isoprene units (MK-9) as the predominant isoprenoid quinone, consistent with members of the genus Curtobacterium (Behrendt et al., 2002). By contrast, species of the genus Rathayibacter possess MK-10 as the predominant menaquinone with a smaller amount $(<20 \%)$ of MK-9 (Suzuki et al., 1997) (Table 1). Strain DCY26 ${ }^{\mathrm{T}}$ contained D-ornithine as the diamino acid in the peptidoglycan, which is commonly found in species of the genus Curtobacterium; members of the genus Rathayibacter possess L-diaminobutyric acid as the diamino acid in the peptidoglycan (Behrendt et al., 2002).

The G + C content of the genomic DNA of strain DCY $26^{\mathrm{T}}$ was $65.8 \mathrm{~mol} \%$. This result was also consistent with data for the genus Curtobacterium.

The 16S rRNA gene sequence of strain DCY $26^{\mathrm{T}}$ was found to be a continuous stretch of $1390 \mathrm{nt}$. The $16 \mathrm{~S}$ rRNA gene sequences of related taxa were obtained from GenBank. Sequence analysis indicated that strain DCY $26^{\mathrm{T}}$ belonged to the genus Curtobacterium within the family Microbacteriaceae. Strain DCY $26^{\mathrm{T}}$ showed highest levels of $16 \mathrm{~S}$ rRNA gene sequence similarity to C. pusillum DSM $20527^{\mathrm{T}}(96.3 \%)$, C. luteum DSM $20542^{\mathrm{T}}(96.2 \%)$, C. flaccumfaciens LMG $3645^{\mathrm{T}}(96.2 \%)$, C. citreum DSM $20528^{\mathrm{T}}$ (96.1\%), C. albidum DSM $20512^{\mathrm{T}}(96.1 \%)$ and C. herbarum DSM $14013^{\mathrm{T}}(95.3 \%)$. In the neighbourjoining phylogenetic tree (Fig. 1), strain DCY $26^{\mathrm{T}}$ clearly belonged to the lineage containing members of the genus Curtobacterium, as evidenced by the high bootstrap value. Based on 16S rRNA gene sequencing, the phylogenetic position of strain DCY $26^{\mathrm{T}}$ among members of the genus Curtobacterium was unique and distinct.

On the basis of phenotypic, chemotaxonomic and phylogenetic data, we concluded that strain DCY $26^{\mathrm{T}}$ represents a novel species of the genus Curtobacterium, for which the name Curtobacterium ginsengisoli sp. nov. is proposed.

\section{Description of Curtobacterium ginsengisoli sp. nov.}

Curtobacterium ginsengisoli (gin.sen.gi.so'li. N.L. n. ginsengum ginseng; L. n. solum soil; N.L. gen. n. ginsengisoli of soil of a ginseng field, the source of the type strain).

Cells are Gram-positive, non-motile, short rods, 0.5$0.8 \mu \mathrm{m}$ in length and $0.3-0.6 \mu \mathrm{m}$ in diameter after growth on R2A agar at $30{ }^{\circ} \mathrm{C}$ for 5 days. Colonies grown on R2A agar plates for 5 days are pale yellow. Grows optimally at $30-37^{\circ} \mathrm{C}$. Growth is observed at $25-42{ }^{\circ} \mathrm{C}$ and at $\mathrm{pH} 5.0$ 11.0 but not at below $4{ }^{\circ} \mathrm{C}$. Positive for oxidase and weakly positive for catalase. Production of indole and acid from glucose is negative. Produces $N$-acetyl- $\beta$-glucosaminidase, acid phosphatase, alkaline phosphatase, $\alpha$-chymotrypsin, cystine arylamidase, esterase, $\alpha$-fucosidase, $\alpha$-galactosidase, $\alpha$-glucosidase, $\beta$-glucuronidase, $\beta$-galactosidase, $\beta$-glucosidase, leucine arylamidase, lipase (C14), naphthol-AS-BIphosphohydrolase and valine arylamidase, but not arginine dihydrolase, $\alpha$-mannosidase, protease, trypsin or urease. Assimilates L-arabinose, D-glucose, maltose, L-rhamnose, sucrose and inositol, but not 2-ketogluconate, 3-hydroxybenzoate, DL-3-hydroxybutyrate, 4-hydroxybenzoate, 5ketogluconate, adipate, caprate, citrate, gluconate, itaconate, lactate, phenyl acetate, L-fucose, D-mannose, melibiose, D-ribose, D-mannitol, D-sorbitol, L-alanine, L- 
Table 1. Differential phenotypic characteristics between strain $\mathrm{DCY} 26^{\top}$ and the type strains of related Curtobacterium and Rathayibacter species

Strains: 1, DCY26 ${ }^{\mathrm{T}}$ (data from the present study); 2, C. albidum DSM 20512 ${ }^{\mathrm{T}}$ (Aizawa et al., 2007; Behrendt et al., 2002); 3, C. ammoniigenes NBRC 101786 ${ }^{\mathrm{T}}$ (Aizawa et al., 2007); 4, C. citreum DSM $20528^{\mathrm{T}}$ (Aizawa et al., 2007; Behrendt et al., 2002); 5, C. flaccumfaciens LMG 3645 (Aizawa et al., 2007; Behrendt et al., 2002); 6, C. herbarum DSM 14013 ${ }^{\mathrm{T}}$ (Behrendt et al., 2002); 7, C. luteum DSM 20542 ${ }^{\mathrm{T}}$ (Aizawa et al., 2007; Behrendt et al., 2002); 8, C. pusillum DSM 20527 (Aizawa et al., 2007; Behrendt et al., 2002); 9, R. caricis VKM Ac-1799 ${ }^{\mathrm{T}}$ (Dorofeeva et al., 2002); 10, R. festucae VKM Ac-1390 ${ }^{\mathrm{T}}$ (Dorofeeva et al., 2002); 11, R. iranicus DSM 7484 ${ }^{\mathrm{T}}$ (Behrendt et al., 2002; Dorofeeva et al., 2002); 12, R. rathayi DSM 7485 ${ }^{\mathrm{T}}$ (Behrendt et al., 2002; Dorofeeva et al., 2002); 13, R. toxicus DSM $7488^{\mathrm{T}}$ (Behrendt et al., 2002; Dorofeeva et al., 2002; Sasaki et al., 1998); 14, R. tritici DSM 7486 ${ }^{\mathrm{T}}$ (Behrendt et al., 2002; Dorofeeva et al., 2002). +, Positive; -, negative; ND, no data available.

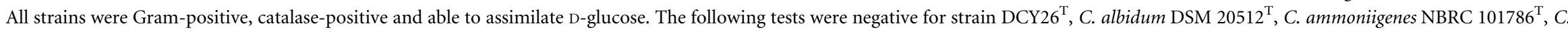
citreum DSM $20528^{\mathrm{T}}$, C. flaccumfaciens LMG $3645^{\mathrm{T}}$, C. luteum DSM $20542^{\mathrm{T}}$ and C. pusillum DSM $20527^{\mathrm{T}}$ (no data available for the other strains): nitrate reduction, urease activity and assimilation of DL-3-hydroxybutyrate, propionate, L-histidine and serine.

\begin{tabular}{|c|c|c|c|c|c|c|c|c|c|c|c|c|c|c|}
\hline Characteristic & 1 & 2 & 3 & 4 & 5 & 6 & 7 & 8 & 9 & 10 & 11 & 12 & 13 & 14 \\
\hline Motility & - & - & - & + & - & + & + & + & - & - & - & - & - & - \\
\hline Cell morphology & Short rods & $\mathrm{ND}$ & Rods & $\mathrm{ND}$ & ND & Rods & $\mathrm{ND}$ & $\mathrm{ND}$ & Rods & Rods & ND & $\mathrm{ND}$ & Rods & $\mathrm{ND}$ \\
\hline Colony colour & Yellow & Ivory & Yellow & Yellow & Yellow & Orange & Yellow & Yellow & Yellow & Orange & Yellow & Yellow & Yellow & Yellow \\
\hline Oxidase & + & - & - & - & - & - & - & - & $\mathrm{W}$ & + & $\mathrm{W}$ & $\mathrm{W}$ & $\mathrm{W}$ & W \\
\hline Growth at $4{ }^{\circ} \mathrm{C}$ & - & $\mathrm{w}$ & - & $\mathrm{w}$ & $\mathrm{w}$ & $\mathrm{w}$ & $\mathrm{w}$ & $\mathrm{w}$ & - & - & $\mathrm{w}$ & $\mathrm{w}$ & $\mathrm{w}$ & $\mathrm{w}$ \\
\hline $\begin{array}{l}\text { Production of acid from } \\
\text { glucose }\end{array}$ & - & + & $\mathrm{ND}$ & + & + & + & + & + & $\mathrm{ND}$ & $\mathrm{ND}$ & + & + & + & + \\
\hline \multicolumn{15}{|l|}{ Enzyme activity } \\
\hline$\alpha$-Glucosidase & + & - & + & + & + & + & + & + & - & - & - & - & - & - \\
\hline$\beta$-Galactosidase & + & - & + & + & + & $\mathrm{ND}$ & + & - & ND & ND & ND & $\mathrm{ND}$ & $\mathrm{ND}$ & $\mathrm{ND}$ \\
\hline$\beta$-Glucosidase & + & + & + & + & + & + & - & + & - & - & + & $\mathrm{w}$ & - & + \\
\hline Protease & - & + & - & - & + & + & - & + & ND & ND & - & - & - & - \\
\hline \multicolumn{15}{|l|}{ Assimilation of: } \\
\hline Citrate & - & - & - & - & - & ND & - & - & - & + & ND & ND & ND & ND \\
\hline Gluconate & - & + & + & - & + & $\mathrm{ND}$ & - & + & $\mathrm{ND}$ & + & ND & $\mathrm{ND}$ & ND & $\mathrm{ND}$ \\
\hline Lactate & - & - & + & $\mathrm{w}$ & + & $\mathrm{ND}$ & $\mathrm{w}$ & - & - & $\mathrm{ND}$ & $\mathrm{ND}$ & $\mathrm{ND}$ & $\mathrm{ND}$ & $\mathrm{ND}$ \\
\hline L-Arabinose & + & + & - & + & + & + & + & + & + & + & + & + & + & + \\
\hline L-Fucose & - & - & - & + & $\mathrm{w}$ & $\mathrm{ND}$ & + & - & - & $\mathrm{ND}$ & ND & $\mathrm{ND}$ & $\mathrm{ND}$ & $\mathrm{ND}$ \\
\hline Melibiose & - & + & + & + & + & + & + & + & + & + & - & - & - & - \\
\hline L-Rhamnose & + & + & - & + & + & + & + & + & + & + & $\mathrm{ND}$ & $\mathrm{ND}$ & $\mathrm{ND}$ & $\mathrm{ND}$ \\
\hline D-Ribose & - & + & ND & + & + & + & + & + & - & - & ND & $\mathrm{ND}$ & $\mathrm{ND}$ & $\mathrm{ND}$ \\
\hline D-Mannitol & - & + & + & + & + & + & + & + & + & + & + & + & + & + \\
\hline D-Sorbitol & - & - & $\mathrm{ND}$ & - & - & + & - & - & + & + & - & - & + & + \\
\hline L-Alanine & - & $\mathrm{w}$ & - & - & + & ND & - & - & ND & ND & ND & $\mathrm{ND}$ & ND & $\mathrm{ND}$ \\
\hline L-Proline & - & - & - & - & + & $\mathrm{ND}$ & - & - & + & + & $\mathrm{ND}$ & $\mathrm{ND}$ & $\mathrm{ND}$ & $\mathrm{ND}$ \\
\hline$N$-Acetyl-D-glucosamine & - & $\mathrm{w}$ & - & + & + & $\mathrm{ND}$ & + & - & $\mathrm{ND}$ & ND & ND & ND & $\mathrm{ND}$ & $\mathrm{ND}$ \\
\hline Glycogen & - & - & - & + & $\mathrm{w}$ & $\mathrm{ND}$ & + & - & ND & $\mathrm{ND}$ & ND & $\mathrm{ND}$ & ND & ND \\
\hline Predominant menaquinone & MK-9 & MK-9 & MK-9 & MK-9 & MK-9 & MK-9 & MK-9 & MK-9 & MK-10 & MK-10 & MK-10 & MK-10 & MK-10 & MK-10 \\
\hline DNA G $+C$ content $(\mathrm{mol} \%)$ & 65.8 & ND & 68.8 & $\mathrm{ND}$ & ND & 71 & $\mathrm{ND}$ & $\mathrm{ND}$ & 68.4 & 68.2 & ND & ND & 60.4 & ND \\
\hline
\end{tabular}




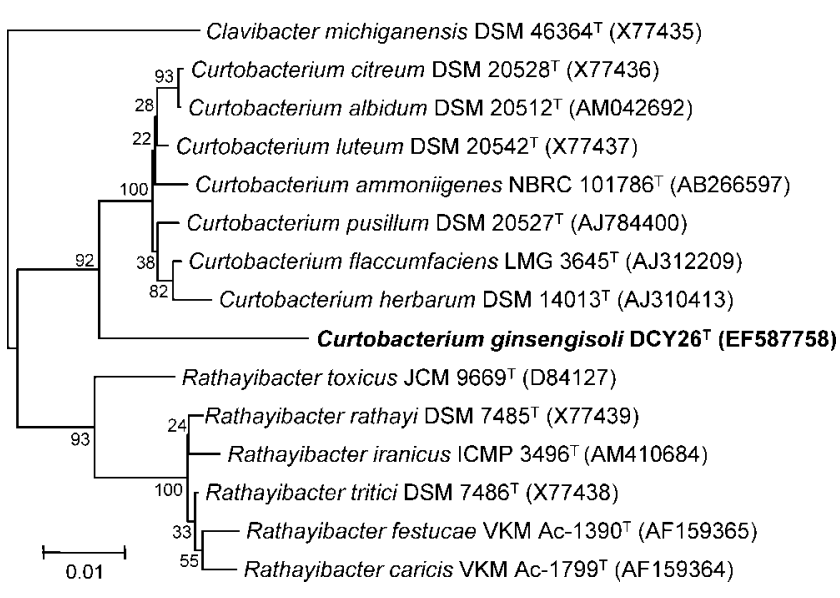

Fig. 1. Neighbour-joining phylogenetic tree showing the relationships among strain DCY $26^{\top}$, Curtobacterium species and members of related genera based on 16S rRNA gene sequences. Bootstrap values are expressed as percentages of 1000 replications at branch points. Bar, 0.01 substitutions per nucleotide position.

histidine, L-proline, L-serine, $N$-acetyl-D-glucosamine, propionate, suberate, $n$-valerate, salicin or glycogen. Does not reduce nitrate to nitrite or to nitrogen gas. The predominant menaquinone is MK-9. The DNA G $+\mathrm{C}$ content of the type strain is $65.8 \mathrm{~mol} \%$, as determined by HPLC.

The type strain, DCY $26^{\mathrm{T}}\left(=\mathrm{KCTC} 13163^{\mathrm{T}}=\mathrm{JCM} 14773^{\mathrm{T}}\right)$, was isolated from soil of a ginseng field in South Korea.

\section{Acknowledgements}

This study was supported by a Korea Science and Engineering Foundation (KOSEF) grant funded by the Korean government (MOST) (no. R01-2006-000-11178-0) and by a BK21 research fellowship from the Ministry of Education and Human Resource Development, Korea.

\section{References}

Aizawa, T., Ve, N. B., Kimoto, K., Iwabuchi, N., Sumida, H., Hasegawa, I., Sasaki, S., Tamura, T., Kudo, T. \& other authors (2007). Curtobacterium ammoniigenes sp. nov., an ammonia-producing bacterium isolated from plants inhabiting acidic swamps in actual acid sulfate soil areas of Vietnam. Int J Syst Evol Microbiol 57, 1447-1452.

Behrendt, U., Ulrich, A., Schumann, P., Naumann, D. \& Suzuki, K. (2002). Diversity of grass-associated Microbacteriaceae isolated from the phyllosphere and litter layer after mulching the sward; polyphasic characterization of Subtercola pratensis sp. nov., Curtobacterium herbarum sp. nov. and Plantibacter flavus gen. nov., sp. nov. Int J Syst Evol Microbiol 52, 1441-1454.

Buck, J. D. (1982). Nonstaining (KOH) method for determination of Gram reactions of marine bacteria. Appl Environ Microbiol 44, 992-993.

Collins, M. D. \& Jones, D. (1981). Distribution of isoprenoid quinone structural types in bacteria and their taxonomic implications. Microbiol Rev 45, 316-354.
Dorofeeva, L. V., Evtushenko, L. I., Krausova, V. I., Karpov, A. V., Subbotin, S. A. \& Tiedje, J. M. (2002). Rathayibacter caricis sp. nov. and Rathayibacter festucae sp. nov., isolated from the phyllosphere of Carex sp. and the leaf gall induced by the nematode Anguina graminis on Festuca rubra L., respectively. Int J Syst Evol Microbiol 52, 1917-1923.

Dunleavy, J. M. (1989). Curtobacterium plantarum sp. nov. is ubiquitous in plant leaves and is seed transmitted in soybean and corn. Int J Syst Bacteriol 39, 240-249.

Felsenstein, J. (1985). Confidence limits on phylogenies: an approach using the bootstrap. Evolution 39, 783-791.

Gavini, F., Mergaert, J., Beji, A., Mielcarek, C., Izard, D., Kersters, K. \& De Ley, J. (1989). Transfer of Enterobacter agglomerans (Beijerinck 1888) Ewing and Fife 1972 to Pantoea gen. nov. as Pantoea agglomerans comb. nov. and description of Pantoea dispersa sp. nov. Int J Syst Bacteriol 39, 337-345.

Hall, T. A. (1999). BioEdit: a user-friendly biological sequence alignment editor and analysis program for Windows 95/98/NT. Nucleic Acids Symp Ser 41, 95-98.

Hedges, F. (1922). A bacterial wilt of the bean caused by Bacterium flaccumfaciens nov. sp. Science 55, 433-434.

Kim, M. K., Im, W.-T., Ohta, H., Lee, M. \& Lee, S.-T. (2005). Sphingopyxis granuli sp. nov., a $\beta$-glucosidase-producing bacterium in the family Sphingomonadaceae in $\alpha-4$ subclass of the Proteobacteria. J Microbiol 43, 152-157.

Kimura, M. (1983). The Neutral Theory of Molecular Evolution. Cambridge: Cambridge University Press.

Kumar, S., Tamura, K., Jakobsen, I. B. \& Nei, M. (2001). MEGA2: molecular evolutionary genetics analysis software. Bioinformatics $\mathbf{1 7}$, 1244-1245.

Mesbah, M., Premachandran, U. \& Whitman, W. B. (1989). Precise measurement of the $\mathrm{G}+\mathrm{C}$ content of deoxyribonucleic acid by highperformance liquid chromatography. Int J Syst Bacteriol 39, 159-167.

Park, Y. H., Suzuki, K., Yim, D. G., Lee, K. C., Kim, E., Yoon, J., Kim, S., Kho, Y. H., Goodfellow, M. \& Komagata, K. (1993). Suprageneric classification of peptidoglycan group B actinomycetes by nucleotide sequencing of $5 \mathrm{~S}$ ribosomal RNA. Antonie van Leeuwenhoek 64, 307-313.

Saitou, N. \& Nei, M. (1987). The neighbor-joining method: a new method for reconstructing phylogenetic trees. Mol Biol Evol 4, 406-425.

Sasaki, J., Chijimatsu, M. \& Suzuki, K. (1998). Taxonomic significance of 2,4-diaminobutyric acid isomers in the cell wall peptidoglycan of actinomycetes and reclassification of Clavibacter toxicus as Rathayibacter toxicus comb. nov. Int J Syst Bacteriol 48, 403-410.

Shin, Y. K., Lee, J.-S., Chun, C. O., Kim, H.-J. \& Park, Y.-H. (1996). Isoprenoid quinone profiles of the Leclercia adecarboxylata KCTC $1036^{\mathrm{T}}$. J Microbiol Biotechnol 6, 68-69.

Suzuki, K., Sasaki, J., Uramoto, M., Nakase, T. \& Komagata, K. (1997). Cryobacterium psychrophilum gen. nov., sp. nov., nom. rev., comb. nov., an obligately psychrophilic actinomycete to accommodate "Curtobacterium psychrophilum" Inoue and Komagata 1976. Int J Syst Bacteriol 47, 474-478.

Takeuchi, M. \& Hatano, K. (1998). Union of the genera Microbacterium Orla-Jensen and Aureobacterium Collins et al. in a redefined genus Microbacterium. Int J Syst Bacteriol 48, 739-747.

Tamaoka, J. \& Komagata, K. (1984). Determination of DNA base composition by reversed phase high-performance liquid chromatography. FEMS Microbiol Lett 25, 125-128.

Thompson, J. D., Gibson, T. J., Plewniak, F., Jeanmougin, F. \& Higgins, D. G. (1997). The CLUSTAL_X windows interface: flexible strategies for multiple sequence alignment aided by quality analysis tools. Nucleic Acids Res 25, 4876-4882. 
Weisburg, W. G., Barns, S. M., Pelletier, D. A. \& Lane, D. J. (1991). 16S ribosomal DNA amplification for phylogenetic study. J Bacteriol 173, 697-703.
Yamada, K. \& Komagata, K. (1972). Taxonomic studies on coryneform bacteria. V. Classification of coryneform bacteria. J Gen Appl Microbiol 18, 417-431. 